\title{
Zooplankton biomass in an eutrophic shallow lake (Buenos Aires, Argentina): spatio-temporal variations
}

\author{
M.C. Claps*, N.A. Gabellone, H.H. Benítez \\ Institute of Limnology « Dr. R. Ringuelet » (CONICET-UNLP), Av. Calchaquí Km. 23,5. 1888 Florencio Varela, Argentina
}

\begin{abstract}
Zooplankton biomass was investigated monthly from September 1997 to August 1998 in a shallow eutrophic lake (San Miguel del Monte, Argentina). Duplicate samples of zooplankton were obtained from three stations with different limnological characteristics. The density of zooplankton community was dominated by rotifers and small cladocerans related to the trophic status of this shallow lake. The zooplankton biomass showed similar values to other eutrophic shallow lakes. The annual biomass distribution was bimodal (winter and summer peaks). The contribution of crustaceans, mainly copepods, determined the total biomass. The total zooplankton biomass was significantly correlated with chlorophyll «a» in the sampling station located at the deep part of this shallow lake. There were factors and processes promoting changes in the zooplankton biomass, such as food availability, grazing ability, fish predation, eutrophication process with alternation of turbid and clear water periods, and also the addition of organisms from the Salado River during floods.
\end{abstract}

Keywords : cladocerans, copepods, clear-turbid periods, predation, rotifers, submerged macrophytes.

\section{Introduction}

The total zooplankton biomass could be useful for estimating the impact of grazers on phytoplankton and, moreover, grazing rates vary with the taxonomic composition, size structure and biomass of zooplankton communities (Cyr \& Pace 1992). Zooplankton, especially cladocerans, play an important role in shallow lakes, which sometimes exhibit two alternative states of equilibrium, condition which is related to the presence or absence of extensive growth of submerged macrophytes (Blindow et al. 1993, Meijer et al. 1994, Jeppesen et al. 1999, Angeler et al. 2002, Claps et al. 2002). The phase with submerged macrophytes (clear water state) is characterised by the dominance of cladocerans because they have refuge from planktivorous fish or invertebrate predators (Moss et al. 1998, Smiley $\&$ Tessier 1998). The development of plankton that efficiently converts nutrients is possible when a sharp

* Corresponding author : E-mail: claps@ilpla.edu.ar. decrease of planktivorous fishes occurs (Carpenter et al. 1985). The phosphorus input is stored in the biomass of zooplankton grazers. These concepts were proposed by Carpenter \& Cottingham (1997), suggesting that resilience capacity of shallow lakes for control of phosphorus cycle depends on longer food webs dominated by piscivorous fishes.

There have been few investigations of zooplankton in pampean shallow lakes (Olivier 1961, Ringuelet et al. 1972). In the last decade, there have been some contributions for particular shallow lakes as Lobos (Boltovskoy et al. 1990), San Miguel (Gabellone et al. 2001, Solari et al. 2002a) and San Miguel del Monte (Benítez \& Claps 2000, Claps et al. 2002). All of these studies emphasised the importance of rotifers and the larval stages of copepods in determining the zooplankton density. There is, however, an absence of information about total zooplankton biomass and about the specific contribution of different components of zooplankton in the vertical profile of temperate shallow lakes.

We analysed the spatio-temporal variation of total 
zooplankton biomass in three sectors of San Miguel del Monte lake, and evaluated the contributions of the major zooplankton groups (rotifers, cladocerans and copepods) as an approach to gaining knowledge of trophic relationships in the plankton of an eutrophic shallow lake typical of the « depressed Pampas ». We also discuss the effect of the presence of submerged macrophytes (Potamogeton pectinatus L.) on zooplankton biomass and which components were more affected. Some factors and processes which would promote changes of zooplankton biomass, such as food availability, grazing ability, fish predation, the eutrophication process with alternation of turbid and clear water periods, and also the incorporation of organisms from the Salado River during floods are also discussed.

\section{Study area}

The San Miguel del Monte lake is small, shallow and eutrophic, and is located in the « depressed Pampa » of NE Buenos Aires province, Argentina (35 $27^{\prime} \mathrm{S}-58^{\circ}$ $\left.48^{\prime} \mathrm{W}\right)$. The area of the lake is approximately 655 ha and mean depth is $1.3 \mathrm{~m}$ (Dangavs 1973). One stream, El Totoral, $21.5 \mathrm{~km}$ long, flows into the lake from an extensive agricultural and cattle breeding area. A town, with 10000 inhabitants, is located on the shore. Floodgates prevent the natural connection with Las Perdices lake and control the water level. During floods of the Salado River, this system of interconnected lakes acts as a backwater in which salinity decreases and into which nutrients enter from the river. The floodgates zone of the lake is clearly related to the frequent exchanges of water and organisms with the connected lake (Las Perdices) and the Salado River. The lake acted as effluent in December, January, July and August and as influent in June. The water level of the lake was influenced by local rainfall and also by rainfall from Salado River headwaters (Fig. 1).

The fish stock of Monte lake comprises 12 autochthonous species and one introduced (Cyprinus carpio L.). The fish community includes two top predators Hoplias malabaricus (Bloch) and Rhamdia sapo Valenciennes, associated with aquatic vegetation and open water habitats, respectively (Freyre 1995). The planktivorous fish (Odonthestes bonariensis Valenciennes) is the main sport fish.

Many shallow lakes in the Salado River basin fluctuate naturally between clear and turbid water conditions in relation to prevailing hydrological regimes. The mechanical harvest of macrophytes is the only manipulation process in the lakes with tourism activity.

\section{Material and methods}

Duplicate samples were taken at four -week intervals during the period September 1997 - August 1998 (except in May due to flood condition) at three sampling stations: one fixed station situated in the deepest sector of the lake $\left(E_{2}\right)$, one located in the connection with Las Perdices lake $\left(\mathrm{E}_{3}\right)$ and one situated in the affluent (El Totoral stream) ( $\left.\mathrm{E}_{1}\right)$. Zooplankton samples $(100 \mathrm{~L})$ were taken using a suction pump every 0.30 meters, from the bottom to the surface during midmorning at $E_{2}$. Sub-surface samples $(100 \mathrm{~L})$ were taken at $E_{1}$ and $E_{3}$. The samples were concentrated through a plankton net of $35 \mu \mathrm{m}$ mesh size and preserved in 5\% formaldehyde. At the same time, some physical and chemical parameters (temperature, $\mathrm{pH}$, conductivity, dissolved oxygen, and turbidity) were measured with a Horiba multimeter. Chlorophyll «a » and total phosphorus (TP) were determined according to APHA (1995).

Rotifers were counted in Sedgwick-Rafter chambers $(1 \mathrm{ml})$ and crustaceans in chambers of $10 \mathrm{ml}$. Zooplankters were identified to genus or species level except for bdelloideans and juvenile copepods. Dry weights of rotifers were estimated from volume measurements using geometric approximations (Ruttner Kolisko 1977), on each sampling date ( $n=10$ to $n=30$ for each taxon sampled). The measured volume was converted to dry weight assuming a specific gravity of 1.0 and a ratio of dry weight to wet weight of $10 \%$ (Mc Cauley 1984). The dry weight of nauplii and copepods was estimated by the method of Lawrence et al. (1987) and Bottrell et al. (1976). Dry weights of cladocerans were estimated on each sampling date from length-weight regressions available for morphologically similar species (Dumont et al. 1975).

Principal Components Analysis (PCA) was performed on a standardized matrix using the dry weight of the main zooplankton groups (Brachionus species, other rotifer species, planktonic cladocerans, nonplanktonic cladocerans, nauplii, adults of cyclopoids and adults of calanoids) at the three sampling stations (in $E_{2}$, the mean total biomass of the vertical profile was used).

\section{Results}

The sampling stations located at San Miguel del Monte lake $\left(\mathrm{E}_{2}\right.$ and $\left.\mathrm{E}_{3}\right)$ had higher dissolved oxygen concentrations, reaching $11.2 \mathrm{mg} \mathrm{L}^{-1}$ in July 1998, than those recorded in El Totoral stream $\left(\mathrm{E}_{1} ; 2.01 \mathrm{mg}\right.$ $\left.\mathrm{L}^{-1}\right)$. The lake was characterised by an alkaline $\mathrm{pH}$ 


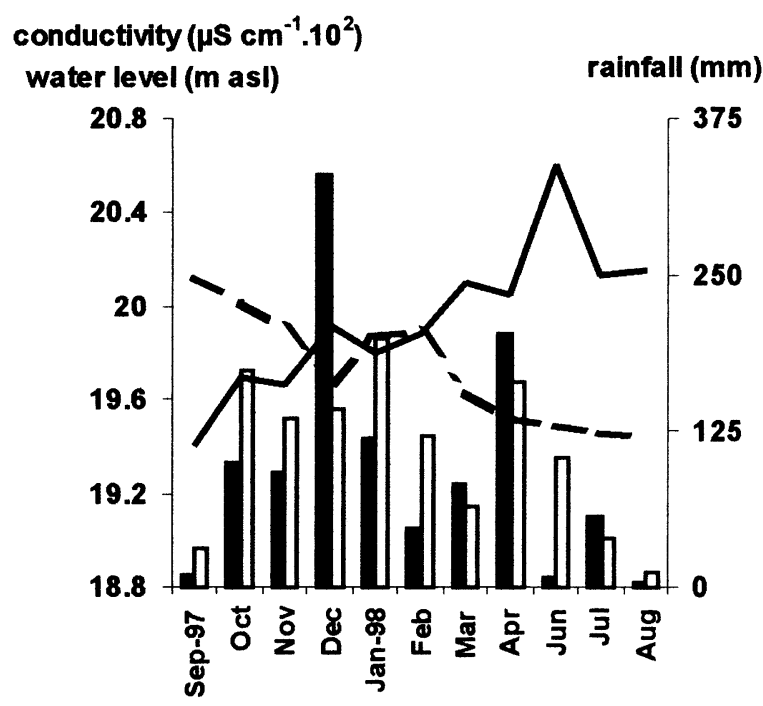

Fig. 1. Monthly variations in local rainfall (black bars), headwaters rainfall (white bars), conductivity (dotted line) and water level (solid line) of San Miguel del Monte lake.

whereas the affluent was neutral, or slightly acid. The maximum conductivity value (Fig. 1$)$ in the lake $(2500$ $\mu \mathrm{S} \mathrm{cm}^{-1}$ ) was recorded at the beginning of the study and decreased to $1300 \mu \mathrm{S} \mathrm{cm}-1$ at the end of the sampling period. The conductivity of El Totoral stream showed the same trend but with a wider range (4400 $\left.800 \mu \mathrm{S} \mathrm{cm}^{-1}\right)$. The concentration of total phosphorus was higher in the stream,(average: $269 \mathrm{~g} \mathrm{~L} \mathrm{~L}^{-1}$; range: 123-464) than in the deeper area of the lake (average: $197.5 \mathrm{\mu g} \mathrm{L}^{-1}$; range: 120-410) and the area near the floodgate (average: $240 \mu \mathrm{g} \mathrm{L}^{-1}$; range:112-570). The chlorophyll «a » values, as an estimation of phytoplankton biomass, were higher at $\mathrm{E}_{2}$ (average: $112 \mathrm{mg}$ $\mathrm{m}^{-3}$; range: $18-475$ ) and $\mathrm{E}_{3}$ (average $98 \mathrm{mg} \mathrm{m}^{-3}$; range: 14-213) than $\mathrm{E}_{1}$ (average $18 \mathrm{mg} \mathrm{m}^{-3}$; range: 6-32). At $E_{2}$ and $E_{3}$, the minimum of chlorophyll « $a »$ occurred in December 1997, whereas the maximum occurred at three occasions, September (turbid water phase), January $\left(E_{2}\right)$ and March (clear water phase). In Totoral stream $\left(E_{1}\right)$, the values and their temporal pattern (maximum in February and June and minimum in November and April) were markedly different from those estimated in the lake.

In El Totoral stream $\left(\mathrm{E}_{1}\right)$, zooplankton densities were not as high as at the other stations, fluctuating between 687 ind. L-1 (March 1998) and 34 ind. L-1 (August 1997). The zooplankton biomass ranged between
214. $\mu \mathrm{g} \mathrm{dw} \mathrm{L}-1$ (June 1998) and $0.38 \mu \mathrm{g} \mathrm{dw} \mathrm{L}^{-1}$ (December 1998) (Fig. 2). The biomass of rotifers was less than $1 \mu \mathrm{g} \mathrm{dw} \mathrm{L} \mathrm{L}^{-1}$, except in November 1997 (2.5 $\mu \mathrm{g}$ $\left.\mathrm{dw} \mathrm{L}^{-1}\right)$, due to the contribution of Brachionus caudatus Barros \& Daday, and in June 1998 (7.5 $\left.\mu \mathrm{g} \mathrm{dw} \mathrm{L}^{-1}\right)$, with Brachionus calyciflorus Pallas as the main species (Fig. 2). Cladocerans, which were scarce or almost completely absent in summer and early autumn (December 1997 - March 1998), reached their maximum biomass in winter (19 $\left.\mu \mathrm{g} \mathrm{dw} \mathrm{L}^{-1}\right)$, mainly through the contribution of Ceriodaphnia cfr. dubia (Fig. 3). The copepods, absent in December 1997, had their peak biomass in winter $\left(192 \mu \mathrm{g} \mathrm{dw} \mathrm{L} \mathrm{L}^{-1}\right)$, with high values in spring and summer $\left(133 \mu \mathrm{g} \mathrm{dw} \mathrm{L} \mathrm{L}^{-1}\right.$ and $131 \mu \mathrm{g} \mathrm{dw} \mathrm{L} \mathrm{L}^{-1}$, respectively). These maxima were generated mainly by cyclopoid and calanoid nauplii (Fig. $3)$.

The zooplankton community of the lake itself $\left(\mathrm{E}_{2}\right)$ was dominated by rotifers, both in terms of specific richness (49 rotifer species) and density (3470 rotifers $\mathrm{L}^{-1}$ in March and 1859 ind $\mathrm{L}^{-1}$ in February 1998). The maximum values of total zooplankton density were also recorded in March and February (3571 and 1920 ind $\mathrm{L}^{-1}$, respectively). The minimum (319 ind $\mathrm{L}^{-1}$ ) occurred in December.

The peaks of total zooplankton biomass (mainly due to the contribution of crustaceans) were observed: two in winter $\left(1271 \mu \mathrm{g} \mathrm{dw} \mathrm{L} \mathrm{L}^{-1}\right.$ and $1595 \mu \mathrm{g} \mathrm{dw} \mathrm{L} \mathrm{L}^{-1}$ in June and August of 1998, respectively) and the third in summer (1422 $\mu \mathrm{g} \mathrm{dw} \mathrm{L}^{-1}$ in January 1998). In spring (October1998) a much smaller zooplankton biomass was recorded (229 $\left.\mu \mathrm{g} \mathrm{dw} \mathrm{L}^{-1}\right)$ (Fig. 2). The maximum biomass of rotifers occurred in late summer (March with $154 \mu \mathrm{g} \mathrm{dw} \mathrm{L}^{-1}$ ) due to the striking contribution of Brachionus species (B. caudatus, B. plicatilis (O. F. M.), $B$. havanensis Rousselet) while the minimum rotifer biomass $\left(1.5 \mu \mathrm{g} \mathrm{dw} \mathrm{L}^{-1}\right)$ was observed in early summer (December, 1997) (Fig. 2). Rotifers had biomass peaks in late spring (November: $174 \mu \mathrm{g} \mathrm{dw} \mathrm{L}^{-1}$ ) in the deeper layers of the vertical profile, due to the presence of $B$. caudatus. During the late summer they were important throughout the water column, with a maxi-

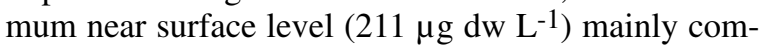
posed of B.caudatus and B. plicatilis (Fig. 2). In general, the maximum average biomass of cladocerans was in the vertical profile $\left(149 \mu \mathrm{g} \mathrm{dw} \mathrm{L}^{-1}\right)$ in December 1997, due to the contribution of Diaphanosoma birgei Korinek. Their minimum average biomass $(13 \mu \mathrm{g} \mathrm{dw}$ $\left.\mathrm{L}^{-1}\right)$ occurred two months later in coincidence with the maximum of rotifer biomass. The cladocerans were important in the layer near the sediments $(456 \mu \mathrm{g} \mathrm{dw}$ $\mathrm{L}^{-1}$ of total biomass) because of the contribution of 


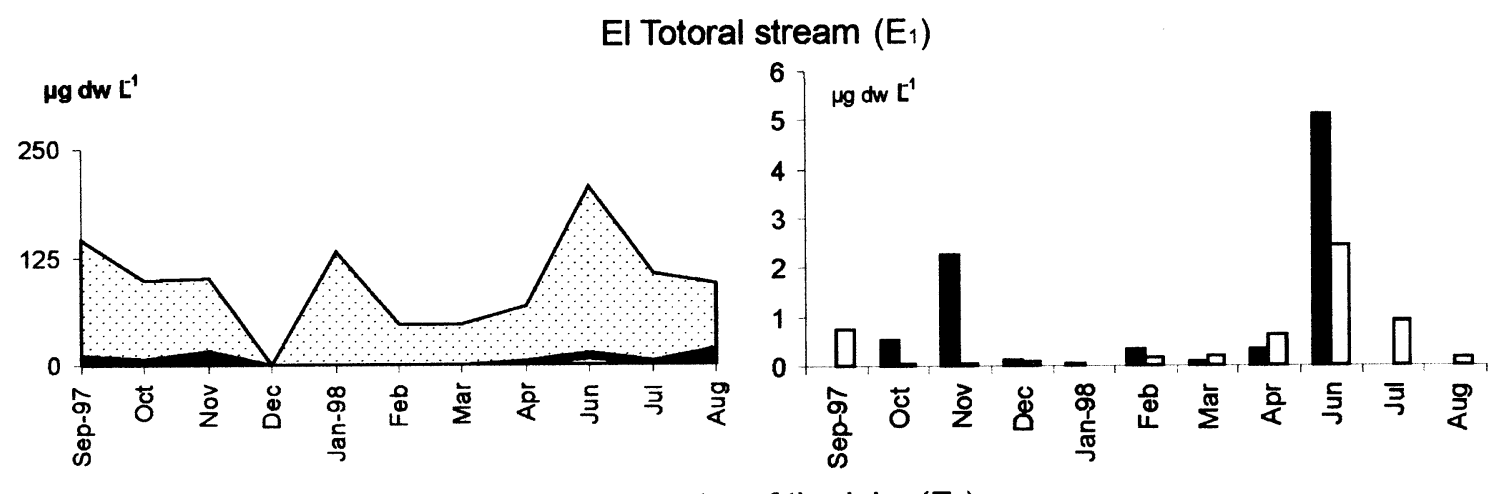

Deep sector of the lake $\left(E_{2}\right)$

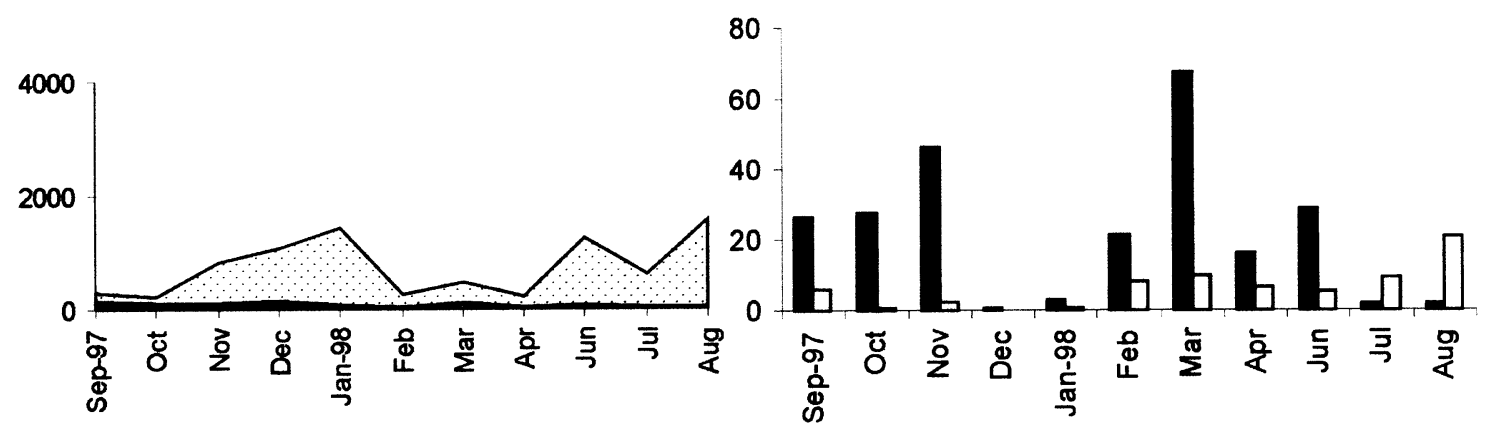

Gates sector of the lake $\left(E_{3}\right)$

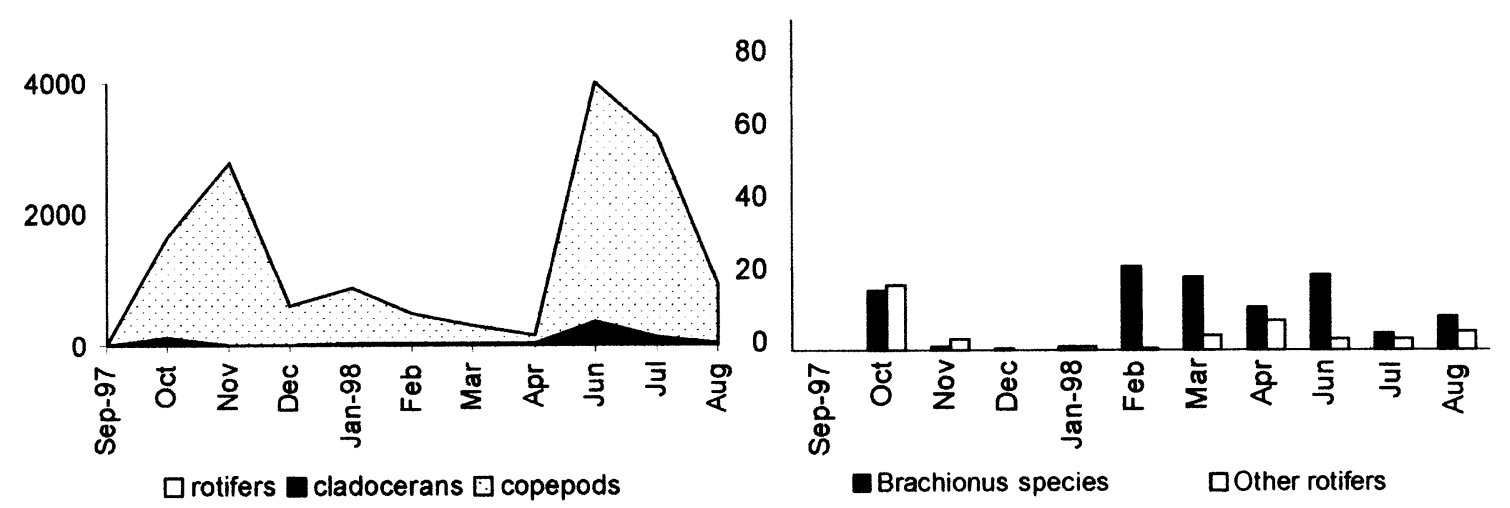

Fig. 2. Comparative monthly changes in the biomass of zooplankton groups and rotifers at the sampling stations.

thycoplanktonic species (Alona spp.) in September 1997 (405 $\mu \mathrm{g} \mathrm{dw} \mathrm{L}^{-1}$ ). In summer, the planktonic cladocerans showed a biomass peak at intermediate layers of the vertical profile (December 1997: $266 \mu \mathrm{g} \mathrm{dw} \mathrm{L-1}$ and January 1998:134 $\mu \mathrm{g} \mathrm{dw} \mathrm{L}^{-1}$ ), with a marked presence of $D$. birgei. The total biomass values of cladocerans were lower than those recorded for copepods (Figs 5b and 6b). Calanoid and cyclopoid copepods 
exhibited three peaks of average biomass which coincided with the total average zooplankton biomass at the vertical profile: in summer with $1346 \mu \mathrm{g} \mathrm{dw} \mathrm{L}^{-1}$ $\left(826 \mu \mathrm{g} \mathrm{dw} \mathrm{L} \mathrm{L}^{-1}\right.$ of nauplii and $520 \mu \mathrm{g} \mathrm{dw} \mathrm{L}^{-1}$ of adults and copepodits), and in winter with $1177 \mu \mathrm{g} \mathrm{dw} \mathrm{\textrm {L } ^ { - 1 }}$ (835 $\mu \mathrm{g} \mathrm{dw} \mathrm{L}^{-1}$ of nauplii and $342 \mu \mathrm{g} \mathrm{dw} \mathrm{L}^{-1}$, adults and copepodits respectively) and $1526 \mu \mathrm{g} \mathrm{dw} \mathrm{L}^{-1}(541$

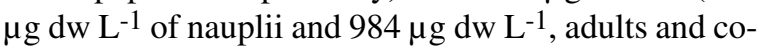

pepodits respectively). The calanoid Notodiaptomus incompositus (Brian) gave the higher biomass values (697 $\mu \mathrm{g} \mathrm{dw} \mathrm{L}{ }^{-1}$ adults plus copepodits in August). The minimum of average biomass of copepods, with $78 \mu \mathrm{g}$ $\mathrm{dw} \mathrm{L}^{-1}\left(41 \mu \mathrm{g} \mathrm{dw} \mathrm{L} \mathrm{L}^{-1}\right.$ of nauplii and $37 \mu \mathrm{g} \mathrm{dw} \mathrm{L}^{-1}$ of adults and copepodits) coincided with the minimum of total zooplankton biomass in October 1997 (Figs. 3b and $6 b$ ).

\section{El Totoral stream ( $\left.E_{1}\right)$}
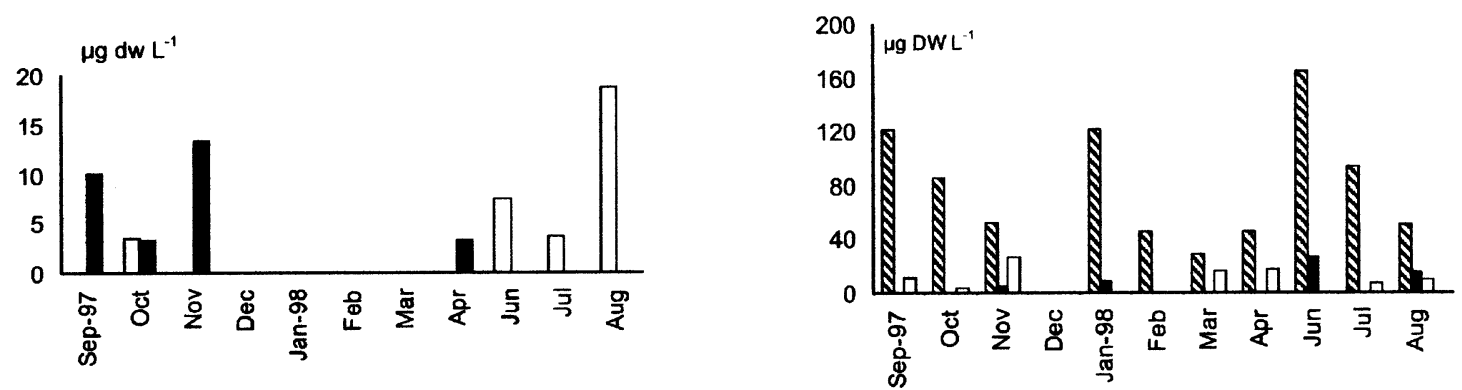

Deep sector of the lake $\left(E_{2}\right)$
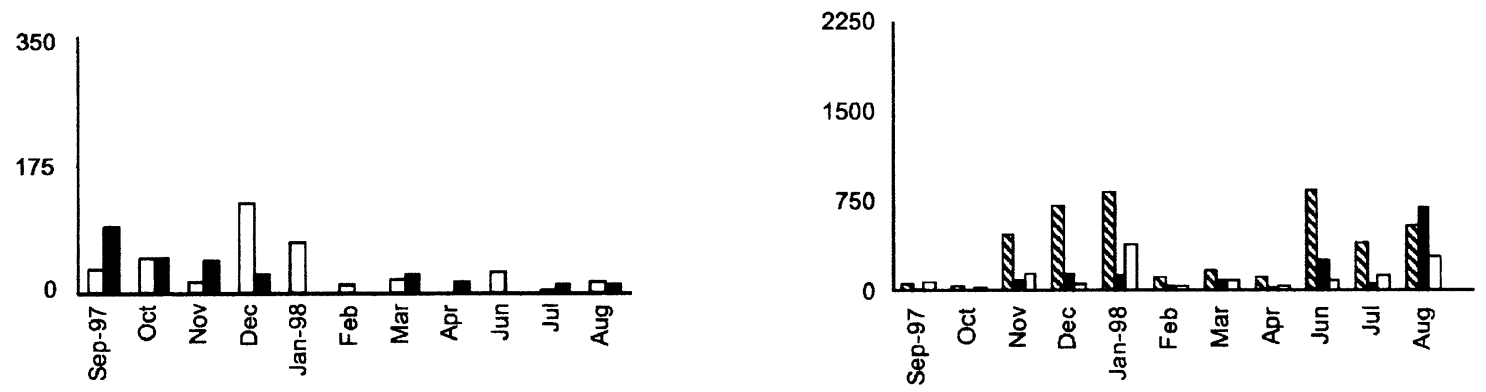

Gates sector of the lake $\left(E_{3}\right)$
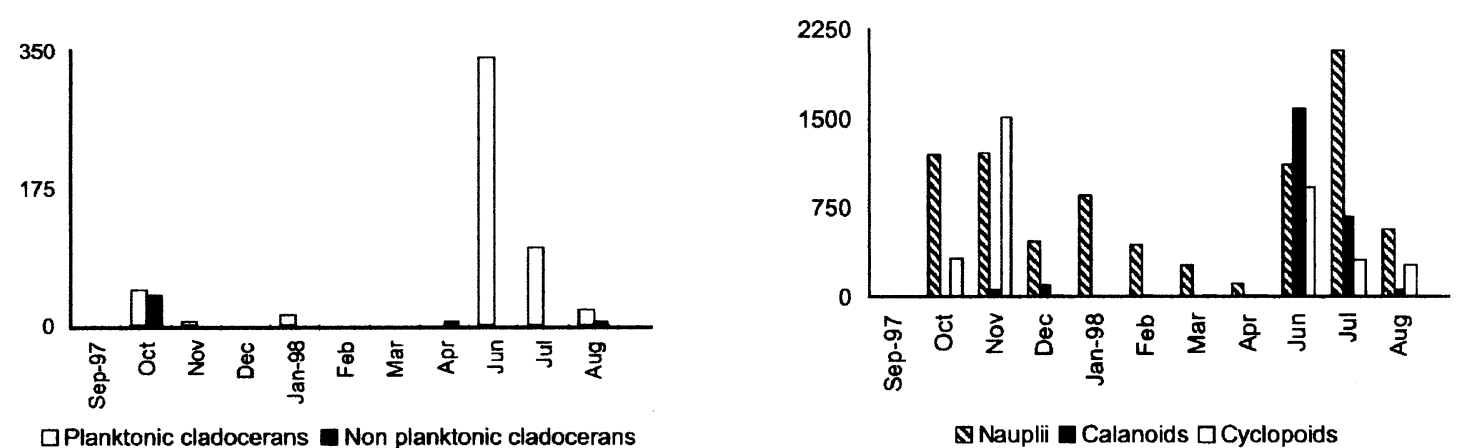

Fig. 3. Comparative monthly changes in the biomass of cladocerans and copepods at the sampling stations. 
In the vertical profile of $E_{2}$, the maximum of total zooplankton biomass occurred at the surface and bottom layers (Fig. 4). Planktonic cladocerans and copepods were relevant in early summer, whereas nauplii and rotifers in autumn. Nauplii and adults of calanoid copepods were responsible for the biomass maximum in winter. Throughout the water column, remarkable biomass deviations were observed. The highest differences were recorded in two occasions (early summer and winter). A uniform vertical distribution of the zooplankton biomass occurred during the maximum cover

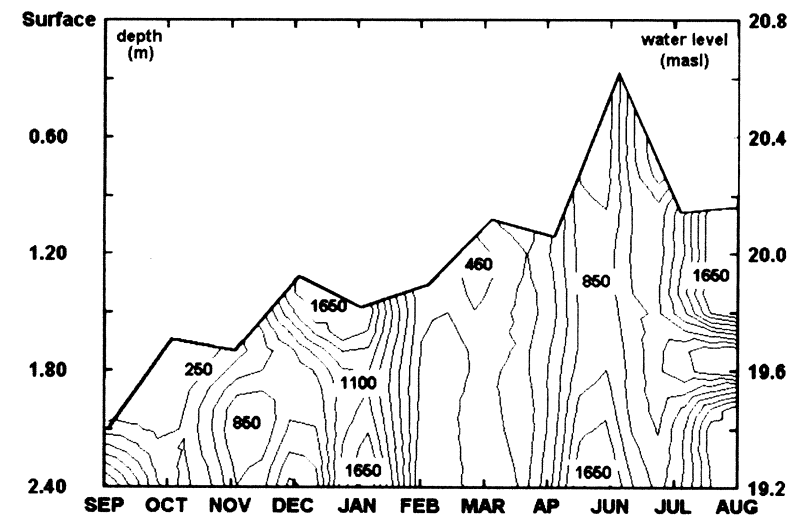

Fig. 4. Monthly vertical distribution of total zooplankton biomass $\left(\mu \mathrm{g} \mathrm{dw} \mathrm{L}{ }^{-1}\right)$ at the deep sector of San Miguel del Monte lake and water level variations (solid line).

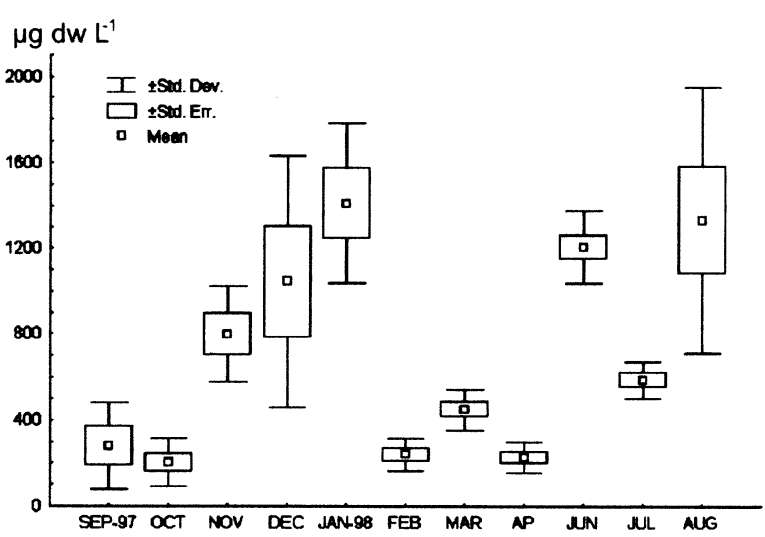

Fig. 5. Box plot of total biomass $\left(\mu \mathrm{g} \mathrm{dw} \mathrm{L}^{-1}\right)$ in the vertical profile at the deep sector of San Miguel del Monte lake. of the submerged macrophytes (February - April) (Fig. 5).

In the area near the gates $\left(E_{3}\right)$, the highest zooplankton density was detected in spring, with a value of 1,626 ind $\mathrm{L}^{-1}$ and the lowest in summer, with 211 ind $\mathrm{L}^{-1}$. The maximum zooplankton biomass was recorded in winter $\left(3,987 \mu \mathrm{g} \mathrm{dw} \mathrm{L}^{-1}\right)$ and the minimum in autumn $\left(180 \mu \mathrm{g} \mathrm{dw} \mathrm{L}^{-1}\right)$ (Fig. 2). The rotifer biomass ranged between $1 \mu \mathrm{g} \mathrm{dw} \mathrm{L}-1$ and $61 \mu \mathrm{g} \mathrm{dw} \mathrm{L} \mathrm{L}^{-1}$, with a maximum in spring due to the contributions of $B$. caudatus and Polyarthra vulgaris Carlin (Fig. 2). The cladocerans, which were scarce and absence in summer and early autumn (December 1997 - April 1998), rea-

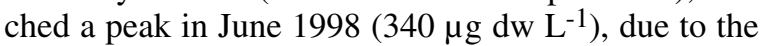
presence of Daphnia spinulata (Birabén) (Fig. 3). Copepods showed three biomass peaks. One generated by calanoid and cyclopoid nauplii plus adults of $N$. incompositus in June 1998 (3627 $\mu \mathrm{g} \mathrm{dw} \mathrm{L} \mathrm{L}^{-1}$, with 1112

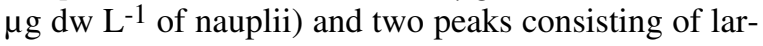
val stages of both cyclopoids and calanoids in November 1997 and July $1998\left(2769 \mu \mathrm{g} \mathrm{dw} \mathrm{L} \mathrm{L}^{-1}\right.$, with $1204 \mu \mathrm{g}$ $\mathrm{dw} \mathrm{L} \mathrm{L}^{-1}$ of nauplii and $3050 \mu \mathrm{g} \mathrm{dw} \mathrm{L} \mathrm{L}^{-1}$, with $2067 \mu \mathrm{g}$ $\mathrm{dw} \mathrm{L} \mathrm{L}^{-1}$ of nauplii, respectively) (Fig. 3).

The first three axes of the Principal Component Analysis explained $65 \%$ of the total variance. Factor 1 (31 $\%$ of the total variance) was positively correlated with the zooplankton biomass recorded in late summer-autumn (April: 0.83, March: 0.76) and negatively with early summer biomass (January: -0.78). Factor $2(19 \%$ of the total variance) was positively correlated with the spring biomass and negatively with the biomass calculated in August and February. Factor 3 (15\% of the total variance) was defined by the winter biomass (June and July) in the positive sector and the summer biomass (January and December) in the negative sector (Fig. 6). Factor 1 included the period with the highest rotifer biomass and the lowest total zooplankton biomass in the positive sector. The opposite sector was defined by nauplii and adults of cyclopoids (January). The second axis, in its negative sector, was related to winter flood condition and high transparency, with highest biomass of calanoids. The opposite extreme was associated with turbid water phase, low water level and the maximum biomass of non-planktonic cladocerans. The winter-interconnected phase with dominance of crustaceans in $\mathrm{E}_{2}$ defined the positive sector (June and July).

\section{Discussion}

The density of zooplankton community of San Mi- 
guel del Monte lake was dominated by rotifers and small cladocerans as expected from the trophic status of the lake and the observations of other research in eutrophic shallow lakes (Gulati 1990, Currie et al. 1999).

The zooplankton biomass in the lake (maximum biomass: $3987 \mu \mathrm{g} \mathrm{dw} \mathrm{L}^{-1}$ ) was similar to that recorded in other eutrophic shallow environments (maximum biomass: $3270 \mu \mathrm{g} \mathrm{dw} \mathrm{L}^{-1}$ ) (Lougheed \& Chou-Fraser 1998). The crustaceans, mainly copepods, dominated the total zooplankton biomass in concordance with the results obtained by Kasprzak \& Koschel (2000). The total zooplankton biomass in the deeper sector of the lake showed maximum values in winter, with a secondary peak in summer, which agree with results obtained in European shallow lakes (Jeppesen et al. 1990).

As in other shallow lakes, in San Miguel del Monte lake, zooplankton community may suffer from fish predation pressure (Freyre 1995). The diet of O. bonariensis during its larval and juvenile periods, mainly consists of planktonic cladocerans and, secondly, of adults of calanoid and cyclopoid copepods (Ringuelet et al. 1980, Grosman 1994, Grosman \& Gonzalez Castelain 1995/1996, Grosman et al. 2002). Other species, such Astyanax eigenmanniorum Malabarba, A. fasciatus Ortega \& Viro and Bryconamericus iheringi Boulenger, categorised as non strictly planktivorous, prey on a great number of planktonic cladocerans (Escalante 1982,1983$)$. This predation was suggested in the fact that the biomass was dominated by copepod nauplii (maximum $67 \%$ of mean total zooplankton biomass in January and July at $\mathrm{E}_{2}$ and $97 \%$ in January at $\mathrm{E}_{3}$ ). Compared to cladocerans, the relative importance of copepods declined ( $18 \%$ of mean total zooplankton biomass in September at $\mathrm{E}_{2}$ ) during the turbid water phase and when the water input increased from the Salado River during floods (28\% of mean total zooplankton biomass in June at $\mathrm{E}_{3}$ ).

The low rotifer biomass may be related to food competition with calanoids and predation pressure of cyclopoids (José de Paggi 1993, 1995). Rotifers exhibited the highest biomass during the maximum submerged macrophytes cover (February - April).

The biomass of medium size cladocerans (Diaphanosoma birgei and Ceriodaphnia cfr. dubia) increased in summer which may be related to the extensive cover of submerged macrophyte in the lake coinciding with the typical developmental period of these cladocerans in other shallow eutrophic systems (Beaver et al. 1999). Moreover, the species responsible for this biomass maximum, D. birgei, prefers high temperatures (Fabián \& Cruz-Pizarro 1997). The macrophyte P. pectinatus could be used by cladocerans as a refuge against vertebrate and invertebrate predation (Jeppesen et al. 1997, Lauridsen et al. 1998) and in these circumstances the rotifers were outcompeted (Lougheed \& Chow-Fraser1998, Scheffer 1998). Biomass of copepod nauplii showed a relative decrease during the maximum of medium-sized cladocerans, a situation perhaps related to competition for food (Nilssen \& Ervågen 2000). The appearance of efficient filter feeders cladocerans (D. spinulata) in winter was due to their arrival in the lake from the Salado River during floods. The percentage of Daphnia spinulata in the total annual biomass was low, which agrees with the results of Jeppesen et al. (1999) in turbid lakes.

At $E_{3}$, the high biomass values were related to the combination of external nutrient loading and the permanent presence of aquatic macrophytes. Only during the clear water period in the lake (January and February 1998 , Secchi disk : 0.70m), was the biomass at $\mathrm{E}_{2}$ higher than at $\mathrm{E}_{3}$.

The low zooplankton biomass in the Totoral stream $\left(E_{1}\right)$ was associated with unfavourable conditions: the percentage saturation of dissolved oxygen was always less than $30 \%$ (except in September 1997 with $72 \%$ ), there were high levels of soluble polyphenols (maximum: $6.25 \mu \mathrm{g} \mathrm{L}^{-1}$ in October 1997) (Ardohain et al. 2000) which are toxic and, the low phytoplankton biomass, reflected in the chlorophyll $a$ concentrations (lower than $35 \mathrm{mg} \mathrm{m}^{-3}$ ), resulted from an influx of allocthonous organic matter.

In $\mathrm{E}_{2}$, the total zooplankton biomass was correlated with chlorophyll $a$ concentrations $\left(\mathrm{r}^{2}: 79.9, \mathrm{P} \leq 0.02\right.$, $\mathrm{n}$ : 58), agreeing with results of Sarnelle et al. (1998) from turbid tropical ponds dominated by small copepods and herbivorous rotifers.

Despite the shallowness of the lake, the standard deviation of the zooplankton biomass was significant three times during the annual cycle in the vertical profile, and was related to the non uniform distribution of larvae and adults of copepods, mainly in December and January. The maximum biomass values, coinciding with maximum phytoplankton densities (Mac Donagh et al. 2000, Solari et al. 2002b), were estimated near the surface

Variations of crustacean biomass revealed modifications in the hydrological conditions of floodgates and lake middle sectors. High biomass values, with predominance of euplanktonic cladocerans (D. spinulata dominated in influent condition) were detected in the floodgate sector during water exchange events with the connected lake (Las Perdices) and the Salado River. In this sector, zooplankton community responded to phy- 

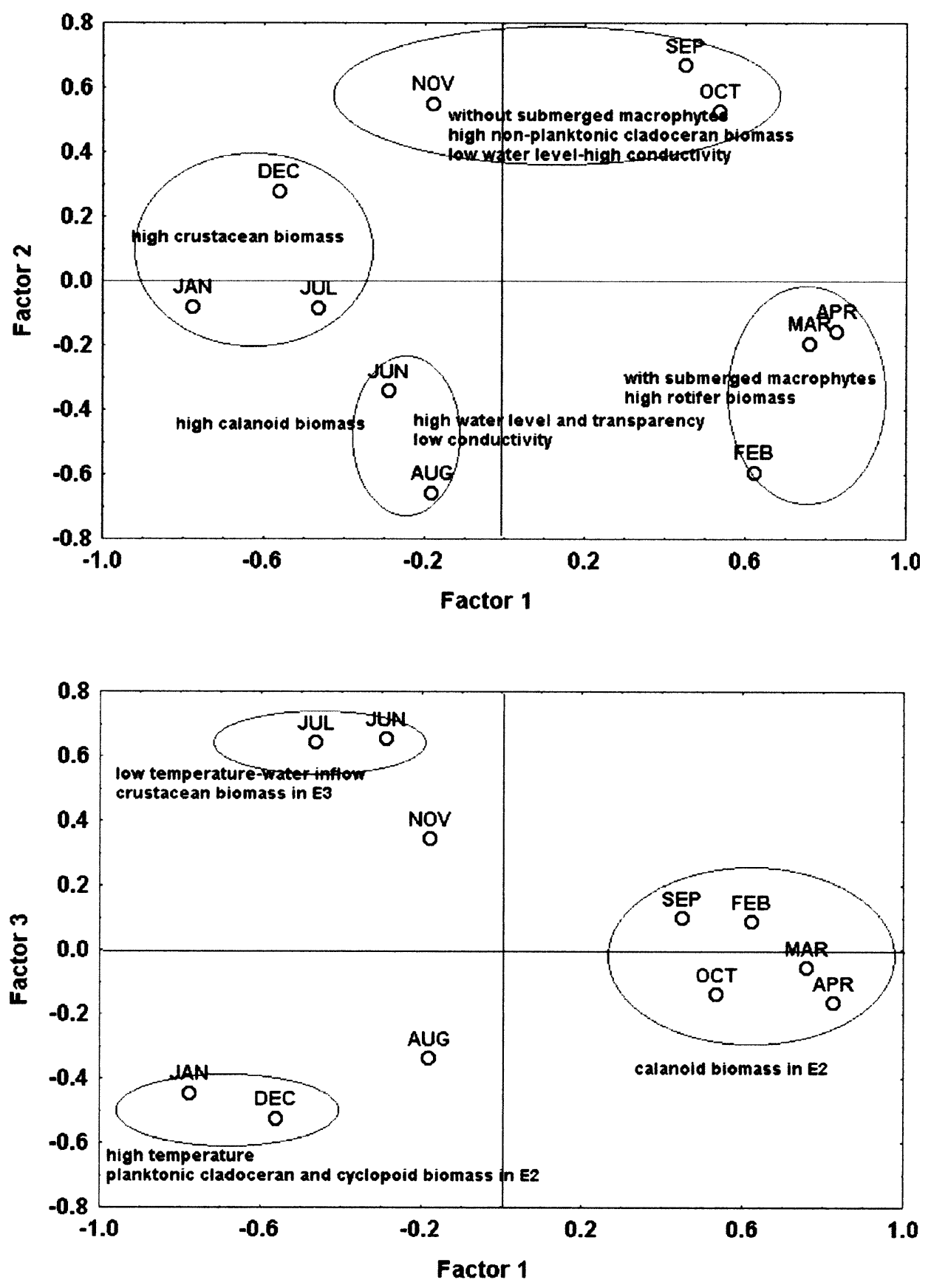

Fig. 6. Bidimensional PCA representation of monthly total zooplankton biomass at two sampling stations $\left(\mathrm{E}_{2}\right.$ and $E_{3}$ ) related to internal biological processes (factor 1), related to water level and conductivity (factor 2) and related to internal biological processes (factor 1) and water inflow and temperature (factor 3). 
sical and biological disturbances by increasing its biomass. Furthermore, the seasonal influence and the presence or absence of macrophytes must be coupled when inflow outflow processes occurred. The nonplanktonic cladocerans were important during turbid water period, with lowest water level and decrease of conductivity. In these conditions, the lowest total biomass occurred, which could be related to planktivorous fish pressure (September and October) (Grosman \& González Castelain 1995/1996, Grosman et al. 2002). A similar situation, with rotifer biomass maximum, was observed after the spawning of planktivorous fishes (February, March and April). In December, euplanktonic cladocerans showed the highest biomass due to the refuge promoted by the appearance of $P$. pectinatus ( Fig. 6).

El Totoral stream, main tributary of the lake, exhibited unfavourable conditions for zooplankton development due to low oxygen saturation percentages and high polyphenol concentrations.

In San Miguel del Monte lake, as elsewhere, various external and internal factors and biological processes stimulated spatio-temporal differences in the zooplankton biomass. Increase of the hydrometric lake level related to local rainfalls or to regional floods and the organism exchange with the Salado River during floods were significant. Food competition, fish predation, the eutrophication process, with alternation of turbid and clear water periods (without and with submerged macrophytes, respectively) as relevant causal factors can be also mentioned.

\section{Acknowledgements}

The authors thank to Municipalidad de San Miguel del Monte, especially the Tourism Secretary, for their collaboration in the extraction of samples. To Mary Morris for improving the English. The investigation was supported by the FONCyT (PMT-PICT 0409), CONICET (PIA 6420) and La Plata University (N 208). Scientific Contribution $\mathrm{N}^{\circ} 762$ of Limnology Institute «Dr. R. Ringuelet».

\section{References}

Angeler D.G., Alvarez Cobelas M., Sánchez-Carrillo S. \& Rodrigo M.A. 2002. - Assessment of exotic fish impacts on water quality and zooplankton in a semiarid floodplain wetland. Aquat. Sci., 64 , 76-86.

APHA. 1995. - Standard Methods for the Examination of Waters and Wastewaters. 19th edn. APHA/AWWA/WPCF. Washington DC.

Ardohain M., Gabellone N., Solari L., Claps M. \& Suarez C. 2000. Influencia de las condiciones hidrológicas sobre algunas características físico-químicas del agua de la laguna de Monte (Pdo de San Miguel del Monte). Diversidad y Ambiente, 1, 21-27.

Beaver J. R., Miller-Lemke A. M. \& Acton J. K. 1999. - Midsummer zooplankton assemblages in four types of wetlands in the Upper Midwest, USA. Hydrobiologia, 380, 209-220.

Benítez H.H. \& Claps M.C. 2000. - Zooplancton de una laguna pampásica (Monte) y su afluente (El Totoral). Caracterización estructural en un ciclo anual. Diversidad y Ambiente, 1, 87-96.

Blindow I., Andersson G., Hargeby A. \& Johansson S. 1993. - Longterm pattern of alternative stable states in two shallow eutrophic lakes. Freshwater Biol., 30, 159-167.

Boltovskoy A., Dippolito A., Foggetta M., Gómez N. \& Alvarez G. 1990. - La laguna Lobos y su afluente: limnología descriptiva, con especial referencia al plancton. Biol. Acuática, 14, 3-38.

Bottrell H., Duncan A., Gliwicz Z., Grygierek E., Herzig A., Hillbricht-Ilkowska A., Kurasawa H., Larsson P. \& Weglenska T. 1976. - A review of some problems in zooplankton production studies. Norw. J. Zool., 24, 419-456.

Carpenter S., Kitchell J. \& Hodgson J. 1985 - Cascading trophic interactions and lake productivity. Bioscience, 35, 634-639.

Carpenter S. \& Cottingham K. 1997. - Resilience and restoration of lakes. Conservation Ecol. (on line) 1: 2 (http.// www.consecol.org).

Claps M., Benítez H. \& Gabellone N. 2002. - Vertical distribution of zooplankton in a pampasic shallow lake (Argentina). Verh. Inter. Ver. Limnol., 28, 1032-1036.

Currie D., Dilworth-Christie P. \& Chapleau F. 1999. - Assessing the strength of top- down influences on plankton abundance in unmanipulated lakes. Can. J. Fish. Aquat. Sci., 56, 427-436.

Cyr H. \& Pace M.L. 1992. - Grazing by zooplankton and its relationship to community structure. Can. J. Fish. Aquat. Sci., 49, 1455-1465.

Dangavs N. V. 1973. - Estudios geológicos en la laguna de San Miguel del Monte. Rev. Museo La Plata (Geología), 8, 1-313

Dumont H., Van De Velde I. \& Dumont S. 1975. - The dry weight estimate of biomass in a selection of Cladocera, Copepoda and Rotifera from the plankton, periphyton and benthos of continental waters. Oecologia, 19, 75-97

Escalante A. H. 1982. - Contribución al conocimiento de las relaciones tróficas de peces de agua dulce del área platense. I. Astyanax eigenmanniorum (Osteichthyes Tetragonopteridae). Limnobios, 2, 311-322.

Escalante A. H. 1983. - Contribución al conocimiento de las relaciones tróficas de peces de agua dulce del rea platense. II. Otros Tetragonopteridae. Limnobios, 2 , 379-402.

Fabián D. \& Cruz-Pizarro L. 1997. - Variaciones espaciales y temporales del zooplancton en un lago monomíctico eutrófico (Lago Ton-Ton, Uruguay). Limnetica, 13, 55-68.

Freyre L. 1995. - Proyecto Estrategias de manejo y evaluación de impacto ambiental. Sistemas fluviales y lacustres de la Pampasia. Informe final Comisión de Investigaciones Científicas. 143 pp.

Gabellone N. A., Solari L. C. \& Claps M.C. 2001. - Planktonic and physical-chemical dynamics of a markedly fluctuating backwater pond associated with a lowland river (Salado River, Buenos Aires, Argentina). Lakes \& Reservoirs. 6, 133-142.

Grosman F. 1994. - Determinación de patrones de alimentación del pejerrey (Odonthestes bonariensis) en ambientes de la provincia de Buenos Aires. Tankay, 1, 238-240.

Grosman F. \& González Castelain J. 1995/1996. - Experiencias de alimentación y crecimiento con alevinos de pejerrey (Odonthestes bonariensis) dirigidas a optimizar la siembra. Rev. Ictiol., 4, 5-10.

Grosman F., Sanzano P. \& Agueria D. 2002. - Aspectos bioecológicos del pejerrey Odonthestes bonariensis de la laguna de Monte. Rev. Mus. Argentino Cienc. Nat., 4, 13-23.

Gulati R. D. 1990. - Structural and grazing responses of zooplankton community to biomanipulation of some Dutch water bodies. $\mathrm{Hy}$ drobiologia, 200/201, 99-118.

Jeppesen E., Søndergaard M. A., Sortjær O., Mortensen E. \& Kristensen P. 1990. - Interactions between phytoplankton, zooplankton and fish in a shallow, hypertrophic lake: study of phytoplankton collapses in Lake Søbygådr, Denmark. Hydrobiologia, 191, 149-164. 
Jeppesen E, Jensen JP, Søndergaard Ma, Lauridsen T, Pedersen L \& Jensen L 1997 - Top-down control in freshwater lakes: The role of nutrient state, submerged macrophytes and water depth. Hydrobiologia, 342-343, 151-164.

Jeppesen E., Jensen J. P., Søndergaard Ma. \& Lauridsen T. 1999. Trophic dynamics in turbid and clearwater lakes with special emphasis on the role of zooplankton for water clarity. Hydrobiologia, 408/409, 217-231.

José de Paggi S. 1993. - Composition and seasonality of planktonic rotifers in limnetic and littoral regions of a flood plain lake (Paraná river system). Rev. Hydrobiol. Trop., 26, 53-63.

José de Paggi S. 1995. - Vertical distribution and diel migration of rotifers in a Paran- River flood plain lake. Hydrobiologia, 310, 87 94.

Kasprzak P. \& Koschel R. 2000. - Lake trophic state, community structure and biomass of crustacean plankton. Verh. Inter. Verein. Limnol., 27, 773-777.

Lauridsen T. L., Jeppesen E., Søndergaard Ma. \& Lodge D. M. 1998. - Horizontal migration of zooplankton: predator - mediated use of macrophyte habitat. Pages 233-239 in Jeppesen E., Søndergaard Ma., Søndergaard Mo. \& Chrisstoffersen K. (eds.). The structuring role of submerged macrophytes in lakes. Ecological Studies 131. Springer Verlag.

Lawrence S. G., Malley D. F., Findlay W., Maciver M. \& Delbaere I. 1987. - Method for estimating dry weight of freshwater planktonic crustaceans from measures of length and shape. Can. J. Fish. Aquat. Sci., 44 (Suppl), 264-274.

Lougheed V. \& Chow-Fraser P. 1998. - Factors that regulate the zooplankton community structure of a turbid, hypereutrophic Great Lakes wetlands. Can. J. Fish. Aquat. Sci., 55, 150-161.

Mac Donagh M., Ruiz G., Solari L. \& Gabellone N. 2000. - Fitoplancton de una laguna de moderada eutrofía en la provincia de Buenos Aires. Diversidad y Ambiente, 1, 37-44.

Mc Cauley E. 1984. - The estimation of the abundance and biomass of zooplankton in samples. Pages 228-265 in Downing J. \& Rigler F. (eds.). A manual on methods for the assessment of secondary productivity in fresh waters. Blackwell Scientific Publications.

Meijer M. L., Jeppesen E., van Donk E., Moss B., Scheffer M., Lammens E., van Nes E., van Berkum J., de Jong G., Faafeng B. \& Jensen J. 1994. - Long-term responses to fish-stock reduction in small shallow lakes: interpretation of five-years results of four biomanipulation cases in the Netherlands and Denmark. Hydrobiologia, 275/276, 457-466.
Moss B., Kornijow R. \& Measey G. J. 1998. - The effect of nymphaeid (Nuphar lutea) density and predation by perch (Perca fluviatilis) on the zooplankton community in a shallow lake. Freshwater Biol., 39, 689-697.

Nilssen J. \& Ervågen S. 2000. - Superficial ecosystem similarities vs autoecological stripping: the «twin species » Mesocyclops leuckarti (Claus) and Thermocyclops oithomoides (Sars) - seasonal habitat utilisation and life history traits. J. Limnol., 59, 79-102.

Olivier S. 1961. - Estudios limnológicos en la laguna Vitel (Pdo. Chascomús-Buenos Aires-Arg.). Agro, 6, 1-128.

Ringuelet R. A., Moreno I. \& Feldman E. 1972. - El zooplancton de las lagunas de la Pampa Deprimida y otras aguas superficiales de la llanura bonaerense (Argentina). Physis, 74, 187-200

Ringuelet R. A., Iriart R. \& Escalante A. H. 1980. - Alimentación del Pejerrey (Basilichthys bonaerensis bonaerensis, Atherinidae) en laguna Chascomús (Buenos Aires, Argentina). Relaciones ecológicas de complementación y eficiencia trófica del plancton. Limnobios, 1, 448-460.

Ruttner-Kolisko A. 1977. - Suggestions for biomass calculations of plankton rotifers. Arch. Hydrobiol., 8, 71-76.

Sarnelle O., Cooper S., Wiseman S. \& Mavuti K. 1998. - The relationship between nutrients and trophic - level biomass in turbid tropical ponds. Freshwater Biol., 40, 65-75.

Scheffer M. 1998. - Ecology of shallow lakes. Pages 1-357 in Usher M., DeAngelis D. \& Manly B. (eds.). Population and Community Biological Series Vol. 22. Kluwer, Dordrecht.

Smiley E. \& Tessier A. 1998. - Environmental gradients and the horizontal distribution of microcrustaceans in lakes. Freshwater Biol., 39, 397-409

Solari L., Claps M. \& Gabellone N. 2002a. - River - backwater pond interactions in the lower basin of the Salado River (Buenos Aires, Argentina). Arch. Hydrobiol. Suppl., 141, 1-21.

Solari L., Mac Donagh M. \& Ruiz G. 2002b. - Vertical distribution of phytoplankton in a pampean shallow lake. Verh. Inter. Verein. Limnol., 28, 1362-1366. 